Research.

\title{
The effect of Corporate Social Responsibility (CSR) and Word Of Mouth (WOM) upon the image of the company (case study at Hotel Whiz Prime Bogor)
}

\author{
VERA CLARA SIMANJUNTAK \\ Department of Management, Economic College of Binaniaga, Bogor, Indonesia \\ veraclarajuntak@gmail.com
}

Received: July 25, 2019; Accepted: August 12, 2019; Published: December 31, 2019

To cite this article: Simanjuntak, Vera Clara. 2019. The Effect of Corporate Social Responsibility (CSR) and Word of Mouth (WOM) upon The Image of The Company (Case Study at Hotel Whiz Prime Bogor). The Management Journal of BINANIAGA. 4 (2): 01-10. doi: 10.33062/mjb.v4i2.331

Abstract. This study aims to explain the Effect of Corporate Social Responsibility (CSR) and Word of Mouth (WOM) upon Corporate Image (Case Study of Bogor Whiz Prime Hotel). The analytical tool used in this study is Multiple Linear Regression which was first tested using validity and reliability tests. The data analysis technique used in this study is using SPSS 24.0 computer statistical software. The sampling method taken was 120 respondents. The results of this study indicate that Corporate Social Responsibility (CSR) has a significant effect on the Image of Whiz Prime Bogor Company, Word of Mouth (WOM) has a significant effect on the Image of Bogor Whiz Prime Hotels, Corporate Social Responsibility (CSR) and Word of Mouth (WOM) simultaneously has been influencing the Company Image of Bogor Whiz Prime Hotel.

Keywords: Corporate Social Responsibility (CSR), Word Of Mouth (WOM), Corporate Image

\section{Introduction}

\section{Background}

Development of tourism business in Indonesia has been signiicanly growing up recently. It is indicated by the increasing of tourists and hotels constructions in Indonesia. Many hotels have been constructed in Bogor which have made pro and contra against hotels construction because they have taken mostly the residence and green area.

Getting along with it, some private corporations, government administrations, public organizations and educational institutions have been creating and promoting corporate social responsibility related with society and environment. They are fully aware that production activities have indirectly been creating negative impact to either social or physical environment surrounding the company that it is necessary for the corporations to perform social activities. Corporations are obliged to execute this kind of social activity absolutely which is Corporate Social Responsibility (CSR) or social responsibility for the companies. Corporate Social Responsibility is very famous words that is mentioned on all companies webs describing their social activities execution.

Corporate Social Responsibility Program or CSR, in general, it is a kind of company awareness about the environment of the neighbourhood. Corporate Social Responsibility (CSR) is a corporate or a business commitment to contribute continuous economic development by being concerned with its social responsibility. When the Program of Corporate Social Responsility (CSR) is developed by the companies, it will give positive impact for their products.

Vera Clara Simanjuntak. The Effect of Corporate Social Responsibility (CSR) and Word of Mouth (WOM) upon The Image of The Company (Case Study at Hotel Whiz Prime Bogor) 
Word of mouth (WOM) is a product or service image being told to other person based on his experiences. If a consumer has transferred positive image of the product or serice to other person, it will be increasing the company image accordingly.

One of the hotels at Jalan Pajajaran Bogor which is Whiz Prime Hotel is under PT Intiwhiz International. PT Intiwhiz International is the famous hotel management provider in Indonesia and Intiwhiz hotel networking is its core business.

PT Intiwhiz International is a subsidiary of PT Intiland Development Tbk, the famous property developer in this country having a lot of world class projects development. All the hotels that are being developed under hotel Intiwhisz management networking is managed according to international quality service standard. It is managed by profesional management team supported by trained and motivated staffs, Intiwhiz has started hospitality business to contribute the development of economy and tourism industries in Indonesia.

Whiz Prime Hotel Bogor was established in 2015. This three-stars hotel has 153 rooms and 12 floors. And it has completed with restaurants, spa, swimming pool, LED TV, and Wi-Fi accessible. Companies can organize business meeting at Whiz Prime Pajajaran Bogor since it has five meeting rooms capacity of 55 to 100 persons.

Whiz Prime Hotel Bogor has been trying to contribute achieving better people quality of living. Good image of the hotel has been maintained accordingly by providing the program of Corporate Social Responsibiliity (CSR). This program is a kind of company's concern which is not only temporary financial donation given to the society, but also to be aware of all stakeholders' needs including the environment and community surrounding the hotel.

Before applying Corporate Social Responsibility (CSR) program, some questions have to be defined before, which society is going to receive it, what success indicator is to be indicated, and what the following-up actions are to be done. CSR program has to be efficient, effective, good quality and reliable which should be executed economically and rationaly to increase the company profit. In order to execute it effectively and efficiently, CSR program needs the tools or technics to be applied in planning and controlling CSR functions related.

\section{Aims of The Research}

This research aims to:

1. Find out the effect of Corporate Social Responsibility (CSR) upon the Company Image.

2. Find out the effect of Words of Mouth (WOM) upon the Company Image.

3. Find out whether Corporate Social Responsibilit (CSR) and Words of Mouth (WOM) have affected the Company Image.

\section{Library Review}

\section{Corporate Social Responsibility (CSR)}

In general, CSR is a kind of social responsibility of a company upon society environment that can be done by performing some usefull social activities for the society leaving nearby the company.

The World Business Council of Sustainable Development (WBCSD) mentioned on Hery (2012:138) has defined as the following:"Corporate Social Responsibility (CSR) is a business commitment of the company to contribute a continuous economic development thru working together with all employees and their representative, family, local community or general society".

Vera Clara Simanjuntak. The Effect of Corporate Social Responsibility (CSR) and Word of Mouth (WOM) upon The Image of The Company (Case Study at Hotel Whiz Prime Bogor) 
Trinidad and Tobaco Bureau of Standards (TTBS) mentioned on Hery (2012:138), CSR is defined as follows: Corporate Social Responsibility (CSR) as a business commitment of a company running its business ethically, legally and contributing the economic development along with the evolvement of emplloyees and their family's quality of life, local community and general society. Referring to the descriptions above, Corporate Social Responsibility (CSR) is the commitment of company to provide longterm contribution over a certain issue coming up in the society or environment to create better environment.

\section{Word of Mouth (WOM)}

Words of mouth (WOM) or verbal communication from one to another which is a communication giving recommendation either individually or group of the people about a certain product or service by transmitting the information personally. Kotler and Keller (2016:278)

Words of mouth (WOM) can be a comment or recommendation spreading over the customers based on the experiences they received, and it has been affecting strongly other people to make their decision.

One of marketing promotion strategy is Word of mouth (WOM) which is a reference for customer's expectation. As it is apart of mixed marketing communication, Word of mouth (WOM is a crucial strategy to affect consumer's decision to purchase the produce or to use the service offered.

\section{Company Image}

Company image is anything related to the customers' perception about a certain company. Suryani (2013:86) Image of a company has been affecting positively the customers' trust. The more positive of customer's perception of the company, the higher the trustworthy of consumer upon the related company. Therefore, it is very important for a company to build up its image thru several activities and communication that should have to be done absolutely. (Suryani, 2013:85) A simple thing to build up the image of a company without spending a lot of money is company website integrated with the program of corporate social responsibility (CSR) or social responsibility of the company which can support the image of the company itself. (Suryani, 2013:85)

\section{Research Methodology}

\section{Type of the Research}

Research method is a scientific study about the system or procedure to execute a research. It means that it is descrbing all the matters about scientific method how to perform a research. However according to Sugiyono (2016:22), research method is a scientific method to obtain the data required for a certain goal and use.

Method of this research has applied associative method finding out the connection between two variables or more. This research is going to describe about the connection between variables affecting and variables being affected.

\section{Population and Sample}

Population is a generalized area consisting of objects or subjects which are having a certain quality and characteristics defined for the purpose of a research. Population of this research is the customers of Hotel Whiz Prime Bogor. And the samples are 120 respondents.

Vera Clara Simanjuntak. The Effect of Corporate Social Responsibility (CSR) and Word of Mouth (WOM) upon The Image of The Company (Case Study at Hotel Whiz Prime Bogor) 


\section{Type and Data Resources}

Data which is applied for this research is primary data. Primary data is origin data or raw data which has been obtained by the writer from the research in the field. Sugiyono (2017:199).

\section{Data Collection Technics}

In order to get the data for this research, the writer has distributed the questionnaires consisting of some declarations for the respondents.

\section{Variables of the Research}

Variables being used in order to ease the research and to make clear the objectives are as follows:

a. Independent variables: Corporate Social Responsibility (CSR) and Word of Mouth (WOM)

b. Dependent variable : Company Image

\section{Data Analysis Method}

This research has applied Multiple Regression Analysis using data processing of SPSS Statistics 240.

\section{Descriptive Statistics}

Descriptive statistics is a statistic analysing the data descriptively or describing the data collected as the sample of the research. Sugiyono (201:25).

\section{Classical Assumption Test}

Classical Assumption Test is to find out whether the regression model designed is useful and good prediction tools. Classical assumption tests which are going to be applied are normality test, multicollinearity test, heteroscedasticity test and autocorrelation test.

\section{Normality Test}

Normality test is to evaluate whether dependent variable and independent variables are having normal distribution or not within the regression model.(Ghozali, 2013:160)

\section{Multicolinearity Test}

Multicolinearity test is to evaluate whether regression model has found out a correlation among the independent variables. Good regression model is when it encounters that there is not any correlation happened among the independent variables. Ghozali (2013:170)

\section{Heteroscedasticity Test}

Heteroscedasticity test is to evaluate whether there is not any variance similarity happened in the regression model which is the residual from one observation to another one. If the variance of residual from one observation to other one is unchanged, it is homoscedasticity, but if it is changed, it is heteroscedasticity. (Ghozali, 2013:139)

\section{Autocorelation Test}

Is a condition happened within regression equation model where it has found out that there is a correlation occurred between error at periode $t$ and other error at periode $t$ 1 (former periode).

Vera Clara Simanjuntak. The Effect of Corporate Social Responsibility (CSR) and Word of Mouth (WOM) upon The Image of The Company (Case Study at Hotel Whiz Prime Bogor) 


\section{Multiple Linear Regression Analysis}

Multiple Linear Regression Analysis is to find out the effect of independent variables which is Corporate Social Responsibility (CSR) and Word of Mouth (WOM) upon dependent variable which is Image of the company. Multiple regression will be used if there is one dependent variable and two or more independent variables exist by using the following regression equation:

Descriptions:

$$
Y=a+b_{1+x_{1}}+b_{2 x_{2}}
$$

$$
\begin{array}{ll}
Y & =\text { dependent variable } \\
\mathrm{a} & =\text { constant number } \\
b_{1,2} & =\text { regression coefficient of independent variables. } \\
X_{1} & =\text { subject when independent variable having a certain value. } \\
X_{2} & =\text { subject when independent variable having a certain value. }
\end{array}
$$

\section{Correlation Analysis}

Is a statistical technique being used to analyze the correlation between two or more variables quantitatively.

\section{Determinant Coefficient Analysis}

Is to measure to what extent the model is capable describing the variation of independent variables.

\section{Hypothesis Test}

Hypotheses test of this research has applied partial test (t-test) and simultaneuous test ( $\mathrm{F}$ test) which is having the connection with the effect of independent variables of Corporate Social Responsibility (CSR) and Word of mouth (WOM) upon the Image of the Company.

\section{Result and Description}

\section{General Information about the Company}

Whiz Prime Hotel Bogor was established in 2015. This three-stars hotel has 153 rooms and 12 floors. And it has completed with restaurants, spa, swimming pool, LED TV, and Wi-Fi accessible. Companies can organize business meeting at Whiz Prime Pajajaran Bogor since it has five meeting rooms capacity of 55 to 100 persons.

\section{Analysis Result of the Research}

\section{Descriptive Statistics}

Table.

Descriptive Statistics

\begin{tabular}{|l|c|r|r|r|r|r|}
\hline \multicolumn{7}{|c|}{ Descriptive Statistics } \\
\hline & $\mathrm{N}$ & Range & Minimum & Maximum & Mean & Std. Deviation \\
\hline CSR & 120 & 17 & 28 & 45 & 39.00 & 3.757 \\
\hline WOM & 120 & 14 & 14 & 28 & 22.60 & 3.094 \\
\hline Company image & 120 & 14 & 19 & 33 & 27.81 & 2.778 \\
\hline Valid N (listwise) & 120 & & & & & \\
\hline
\end{tabular}

Source: processed data SPSS 24,2019

Vera Clara Simanjuntak. The Effect of Corporate Social Responsibility (CSR) and Word of Mouth (WOM) upon The Image of The Company (Case Study at Hotel Whiz Prime Bogor) 
The Management Journal of BINANIAGA Vol. 04, No. 02, December 2019

p-ISSN: 2527 - 4317, e-ISSN: $2580-149 x$

$6^{\text {th }}$ Accreditation Rating: April 04, 2019- April 03, 2024

\section{Classical Assumption Test}

\section{Normality Test}

Normality test is to evaluate whether dependent variable and independent variables are having normal distribution or not within regression model.

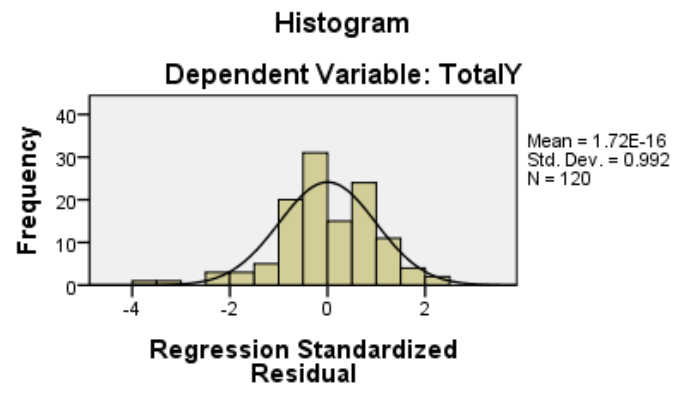

Source: processed data SPSS 24,2019

Histogram graph of Normality Test

Multicolinearity Test

Table 2

Multicolinearity Test

\begin{tabular}{|c|c|c|c|c|c|c|c|c|}
\hline \multicolumn{9}{|c|}{ Coefficients $^{a}$} \\
\hline \multirow{2}{*}{\multicolumn{2}{|c|}{ Model }} & \multicolumn{2}{|c|}{$\begin{array}{l}\text { Unstandardized } \\
\text { Coefficients }\end{array}$} & \multirow{2}{*}{$\begin{array}{c}\text { Standardized } \\
\text { Coefficients } \\
\text { Beta } \\
\end{array}$} & \multirow[b]{2}{*}{$t$} & \multirow[b]{2}{*}{ Sig. } & \multicolumn{2}{|c|}{ Collinearity Statistics } \\
\hline & & $B$ & Std. Error & & & & Tolerance & VIF \\
\hline \multirow[t]{3}{*}{1} & (Constant) & 9.422 & 2.096 & & 4.496 & .000 & & \\
\hline & TotalX1 & .351 & .064 & .474 & 5.469 & .000 & 677 & 1.477 \\
\hline & TotalX2 & .208 & .078 & .232 & 2.672 & .009 & .677 & 1.477 \\
\hline
\end{tabular}

Source : Processed data SPSS 24, 2019

Based on the output of the table above, it is indicating Tolerance value of $>0.1$ and VIF value of $<10$, it is explaining that there is not any multicollinearity happened and this regression model is applicable.

\section{Heteroscedasticity Test}

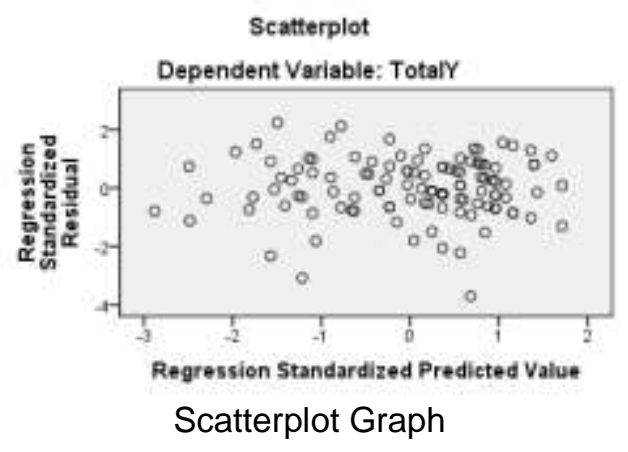

Refers to Scatterplot Graph, it is indicating that there is not any clear patern and plots are scaterring over and under 0 (nul) figure at $Y$ line, so that there is not any heteroscedasticity happened.

Vera Clara Simanjuntak. The Effect of Corporate Social Responsibility (CSR) and Word of Mouth (WOM) upon The Image of The Company (Case Study at Hotel Whiz Prime Bogor) 
Table.

Autocorrelation Test

\begin{tabular}{|l|c|c|c|c|r|}
\hline \multicolumn{7}{|c|}{ Model Summary } \\
\hline Model & $\mathrm{R}$ & R Square & $\begin{array}{c}\text { Adjusted R } \\
\text { Square }\end{array}$ & $\begin{array}{c}\text { Std. Error of the } \\
\text { Estimate }\end{array}$ & Durbin-Watson \\
\hline 1 & $.635^{\mathrm{a}}$ & .404 & .394 & 2.164 & 1.708 \\
\hline a. Predictors: (Constant), TotalX2, TotalX1 \\
\hline \multicolumn{2}{|l|}{ b. Dependent Variable: TotalY } \\
\hline
\end{tabular}

Source: Data Processed SPSS 24, 2019

Refers to the result of the test using Durbin-Watson, it is indicating that DW value of 1.958 and table value of total $\mathrm{n}$ sample $=120$, $\mathrm{dl}$ value $=1.6684$, and $\mathrm{du}=1.7361$ where $\mathrm{DL}$ value $<\mathrm{DW}<\mathrm{DU}, 1.6684<1.708<1.7361$, it is explaining that there is not any autocorrelation happened.

\section{Multiple Linear Regression Analysis Test}

Table.

Result of Multiple Linear Regression Analysis Test.

\begin{tabular}{|c|c|c|c|c|c|c|}
\hline \multicolumn{7}{|c|}{ Coefficients $^{\mathrm{a}}$} \\
\hline \multirow{2}{*}{\multicolumn{2}{|c|}{ Model }} & \multicolumn{2}{|c|}{$\begin{array}{l}\text { Unstandardized } \\
\text { Coefficients }\end{array}$} & \multirow{2}{*}{$\begin{array}{c}\text { Standardized } \\
\text { Coefficients } \\
\text { Beta } \\
\end{array}$} & \multirow[b]{2}{*}{ ? } & \multirow[b]{2}{*}{ Sig. } \\
\hline & & B & $\begin{array}{l}\text { Std. } \\
\text { Error }\end{array}$ & & & \\
\hline 1 & (Constant) & 9.422 & 2.096 & & 4.496 & .000 \\
\hline & TotalX1 & 351 & .064 & .474 & 5.469 & .000 \\
\hline & TotalX2 & 208 & .078 & .232 & 2.672 & .009 \\
\hline
\end{tabular}

Source: data processed SPSS 24, 2019

$$
Y=9,422+0,351 . X 1+0,208 . X 2
$$

The Regression equation above is describing as follow:

1. Constant value of 9.422 has explained that if independent variables of Corporate Social Responsibility (CSR) and Word of mouth (WOM) are constant or do not change, then image of the company will increase about 9.422 .

2. Coefficient value of regression $X 1=0.351$ has explained that if Corporate Social Responsibility (CSR) at Hotel Whiz Prime Bogor is increased but variable Word of mouth (WOM) is constant(does not change), therefore, Image of the Company will increase 0.351 .

3. Coefficient value of regression $\mathrm{X} 2=0.208$ has explained that if Word of mouth (WOM) at Hotel Whiz Prime Bogor is increased but Corporate Social Responsibiliity (CSR) variable is constant (not any change happened), then Image of the Company will be increasing 0.208 .

Vera Clara Simanjuntak. The Effect of Corporate Social Responsibility (CSR) and Word of Mouth (WOM) upon The Image of The Company (Case Study at Hotel Whiz Prime Bogor) 


\section{Correlation Test}

Table.

Result of Correlation Test

\begin{tabular}{|c|c|c|c|c|}
\hline \multicolumn{5}{|c|}{ Correlations } \\
\hline & & TotalX1 & TotalX2 & TotalY \\
\hline \multirow[t]{3}{*}{ TotalX1 } & Pearson Correlation & 1 & $.568^{* *}$ & $.606^{* *}$ \\
\hline & Sig. (2-tailed) & & .000 & .000 \\
\hline & $\mathrm{N}$ & 120 & 120 & 120 \\
\hline \multirow[t]{3}{*}{ TotalX2 } & Pearson Correlation & $.568^{* *}$ & 1 & $.501^{* *}$ \\
\hline & Sig. (2-tailed) & .000 & & .000 \\
\hline & $\mathrm{N}$ & 120 & 120 & 120 \\
\hline \multirow[t]{3}{*}{ TotalY } & Pearson Correlation & $.606^{* *}$ & $.501^{* *}$ & 1 \\
\hline & Sig. (2-tailed) & .000 & .000 & \\
\hline & $\mathrm{N}$ & 120 & 120 & 120 \\
\hline
\end{tabular}

Source : data processed SPSS 24, 2019

Correlation between Corporate Social Responsibility (CSR) X1 and Image of the company $(\mathrm{Y})$ is 0.606 which is strong criteria, and positive direction, it has explained that if Corporate Social Responsibility (CSR) (X1) is increased, Image of the company will increase as well. Correlation between Word of mouth (WOM) (X2) and Image of the company $(\mathrm{Y})$ is 0.501 which is strong criteria and positive direction, it means that Word of mouth (WOM) (X2) has increased, therefore, Image of the company $(\mathrm{Y})$ will be increasing as well. Significant value between Corporate Social Responsibility (CSR) and Word of mouth (WOM) over Image of the company is $0.000<0.05$, it has explained that a correlation between 2 independent variables has happened upon dependent variable.

\section{T-test Result}

Table.

T-test Result

\begin{tabular}{|c|c|c|c|c|c|c|}
\hline \multicolumn{7}{|c|}{ Coefficients $^{\mathrm{a}}$} \\
\hline \multirow{2}{*}{\multicolumn{2}{|c|}{ Model }} & \multicolumn{2}{|c|}{$\begin{array}{l}\text { Unstandardized } \\
\text { Coefficients }\end{array}$} & \multirow{2}{*}{$\begin{array}{c}\begin{array}{c}\text { Standardized } \\
\text { Coefficients }\end{array} \\
\text { Beta } \\
\end{array}$} & \multirow[b]{2}{*}{$t$} & \multirow[b]{2}{*}{ Sig. } \\
\hline & & B & $\begin{array}{l}\text { Std. } \\
\text { Error }\end{array}$ & & & \\
\hline 1 & (Constant) & 9.422 & 2.096 & & 4.496 & .000 \\
\hline & TotalX1 & .351 & .064 & .474 & 5.469 & .000 \\
\hline & TotalX2 & .208 & .078 & .232 & 2.672 & .009 \\
\hline
\end{tabular}

Source : data processed SPSS 24, 2019

Result of the test has described that $\mathrm{t}$-count for Corporate Social Responsibility (CSR) is 5.469 and Word of mouth (WOM) is 2.672. T-table value is 1.98027.

T-count of Corporate Social Responsibility (CSR) is $5.469>\mathrm{t}$-table of 1.98027 , therefore, Ho is rejected. Nevertheless, Corporate Social Responsibility (CSR) has affected significantly the Image of company. T-count of Word of mouth (WOM) is 2.672 $>\mathrm{t}$-table of 1.98027, therefore, Ho is rejected. Nevertheless, Word of mouth (WOM) has affected significantly the Image of company.

Vera Clara Simanjuntak. The Effect of Corporate Social Responsibility (CSR) and Word of Mouth (WOM) upon The Image of The Company (Case Study at Hotel Whiz Prime Bogor) 


\section{Result of F-test}

Table.

Result of F-test

\begin{tabular}{|c|c|c|c|c|c|c|}
\hline \multicolumn{7}{|c|}{ ANOVAa $^{a}$} \\
\hline \multicolumn{2}{|c|}{ Model } & Sum of Squares & df & Mean Square & $\mathrm{F}$ & Sig. \\
\hline \multirow[t]{3}{*}{1} & Regression & 370.916 & 2 & 185.458 & 39.619 & $.000^{\mathrm{b}}$ \\
\hline & Residual & 547.676 & 117 & 4.681 & & \\
\hline & Total & 918.592 & 119 & & & \\
\hline \multicolumn{7}{|c|}{ a. Dependent Variable: TotalY } \\
\hline \multicolumn{7}{|c|}{ b. Predictors: (Constant), TotalX2, TotalX1 } \\
\hline
\end{tabular}

Source : data processed SPSS 24, 2019

Referring to the result on the table above, F-count is 39.619 , but F-table is 3.07 . . The calculation result above has shown that F-count of $39.619>\mathrm{F}$-table of 3.07, it means that $\mathrm{Ho}$ is rejected and $\mathrm{Ha}$ is accepted, so that, Corporate Social Responsibility (CSR)and Word of mouth simultaneously has significantly affected Image of the company.

\section{Determinant Coefficient Test}

Table 8

Result of Determinant Coefficient Test

\begin{tabular}{|l|c|c|c|c|r|}
\hline \multicolumn{7}{|c|}{ Model Summary $^{\text {b }}$} \\
\hline Model & $\mathrm{R}$ & R Square & $\begin{array}{c}\text { Adjusted R } \\
\text { Square }\end{array}$ & $\begin{array}{c}\text { Std. Error of the } \\
\text { Estimate }\end{array}$ & Durbin-Watson \\
\hline 1 & $.635^{\mathrm{a}}$ & .404 & .394 & 2.164 & 2.058 \\
\hline a. Predictors: (Constant), TotalX2, TotalX1 & & \\
\hline \multicolumn{7}{|l}{ b. Dependent Variable: totally }
\end{tabular}

Source: data processed SPSS, 2019

The value of determinant coefficient can be identified on the Adjusted R.Square of 0.394 and this result has explaind that $39.4 \%$ refers to the variation of Company Image which can be described by both independent variables of Corporate Social Responsibility (CSR) and Word of mouth (WOM). However the remaining of $60.6 \%$ has not been described in this research.

\section{Conclusion and Suggestions}

\section{Conclusion}

This research aims to recognize the Effect of Corporate Social Responsibility (CSR) and Word of Mouth (WOM) upon the Image of the Company at Hotel Whiz Prime Bogor. Based on the calculation and description mentioned on the previous chapters, it could be concluded as follows:

1. Corporate Social Responsibility (CSR) has affected significantly the Image of the Company which is Hotel Whiz Prime Bogor. it refers to the result of t-count of $5.469>$ $\mathrm{t}$-table of 1.98027

2. Word of Mouth (WOM) has affected significantly the Image of Company which is Hotel Whiz Prime Bogor. It refers to the result of t-count of $2.672>\mathrm{t}$-table of 1.98027.

3. Corporate Social Responsibility (CSR) and Word of Mouth (WOM) simultaneously has affected the Image of the Company which is Hotel Whiz Prime Bogor.

Vera Clara Simanjuntak. The Effect of Corporate Social Responsibility (CSR) and Word of Mouth (WOM) upon The Image of The Company (Case Study at Hotel Whiz Prime Bogor) 
The Management Journal of BINANIAGA Vol. 04, No. 02, December 2019

p-ISSN: $2527-4317$, e-ISSN: $2580-149 x$

$6^{\text {th }}$ Accreditation Rating: April 04, 2019-April 03, 2024

\section{Suggestions}

Based on the result of the research and conclusion above, the following suggestions could be offered:

1. For the company

Management of Hotel Whiz Prime Bogor is expected to be able to improve the program of Corporate Social Responsiility (CSR) and Word of Mouth (WOM) better. Because running both of them better will be increasing profit value of the company.

2. For further researcher

Since the writer has applied two independent variables and one dependent variable in this research, it would be better next researcher will add other variables affecting the Image of the Company of Hotel Whiz Prime Bogor.

\section{References}

Fatmasari, Revina And Ika, Yoga M.M, (2018) Pengaruh Corporate Social Responsibility (CSR) Terhadap Word Of Mouth (WOM) Dengan Reputasi Perusahaan Sebagai Variabel Mediasi Studi Pada Konsumen Aqua Wilayah Klaten. Skripsi Thesis, IAIN Surakarta.

Ghozali, Imam. (2013). Aplikasi Analisis Multivariate dengan Program SPSS. Semarang: Badan Penerbit UniversitasDiponegoro.

Hery. 2012. Akuntansi \& Rahasia dibaliknya untuk Para Manajemen Non-. Akuntansi. Jakarta: PT Bumi Aksara.

Kotler, Philip and Kevin Lane Keller, (2016): Marketing Management, 15th. New Jersey: Pearson Prentice Hall, Inc.

Purwanto, Suhardjanto Djoko, Warto dan Supriyadi, 2018, Existing Program Tanggungjawab Sosial (CSR) Hotel Berbintang terhadap masyarakat di kota Surakarta, Prosiding SENDI_U 2018. ISBN: 978-979-3649-99-3.

Robert Pancayoga Bode Lumanaw, Christoffel M. O. Mintardjo (2017). Pengaruh Kualitas Pelayanan Dan Corporate Social Responsibility Terhadap Kepuasan Konsumen Pt. Galesong Mandiri Cabang Kairagi Manado. Jurnal EMBA Vol.5 No.2 September 2017. ISSN. 2303-1174.

Suryani, Tatik. 2013. Perilaku Konsumen di Era Internet. Yogyakarta: Graha. IImu.

Silvania Mira Vegawati (2015). Pengaruh Program Corporate Social Responsibility Terhadap Citra Perusahaan (Survey Pada warga di desa Sidodadi Kelurahan Kalirejo Kec Lawang Malang ), Jurnal Administrasi Bisnis (JAB) Vol. 20 No. 1 Maret 2015, ISSN (Online) 2599-0837.

Sugiyono. (2016). Metodologi Penelitian Kuantitatif, Kualitatif, dan R\&D. Bandung: CV Alfabeta.

Sugiyono. (2017). Metode Penelitian Kuantitatif, Kualitatif, dan R\&D. Bandung: Alfabeta.

Singgih Santoso (2017), Menguasai Statistik dengan SPSS 24. Penerbit, Elex Media Komputindo, 2017. ISBN, 6020401936.

Yosa Vega Prasiska, Bunga Pertiwi, Yosi Rizky Nabila, Kristin Indah , Dian Safitri (2017), CSR Dan Citra Perusahaan (Survei pada Waga Sekitar PT Pandatex). Jurnal Bisnis dan Ekonomi (JBE), Maret 2017. ISSN: 1412-3126.

Vera Clara Simanjuntak. The Effect of Corporate Social Responsibility (CSR) and Word of Mouth (WOM) upon The Image of The Company (Case Study at Hotel Whiz Prime Bogor)

Page : 10 